\title{
Distribution of rs1801279 and rs1799930 Polymorphisms in NAT2 Gene among Population in Kupang, Nusa Tenggara Timur, Indonesia
}

\author{
Edhyana Sahiratmadja ${ }^{1, *}$, Simeon Penggoam², Ani Melani Maskoen ${ }^{1,3}$, Alvinsyah Adhityo Pramono $^{4}$, \\ Dias Aryani ${ }^{5}$, Nurul Setia Rahayu ${ }^{4}$, Ramdan Panigoro ${ }^{1}$ \\ ${ }^{1}$ Department of Biochemistry \& Molecular Biology, Faculty of Medicine Universitas Padjadjaran, Jl. Eijkman No.38, Bandung, Indonesia \\ ${ }^{2}$ Laboratorium Mikrobiologi, Prof. Dr. W.Z. Johannes Hospital, Jl. Dr. Muh. Hatta 19, Fontein Oebobo, Kupang, Indonesia \\ ${ }^{3}$ Department of Oral Biology, Faculty of Dentistry, Universitas Padjadjaran, Jl. Eijkman No.38, Bandung, Indonesia \\ ${ }^{4}$ Health Research Unit, Faculty of Medicine Universitas Padjadjaran, Jl. Eijkman No.38, Bandung, Indonesia \\ ${ }^{5}$ Department of Biology, Faculty of Natural Sciences, Universitas Padjadjaran, Jl. Eijkman No.38, Bandung, Indonesia \\ *Corresponding author. E-mail: e.sahiratmadja@unpad.ac.id
}

Received date: Jun 12, 2017; Revised: Sep 14, 2017; Accepted: Oct 9, 2017

\section{Abstract}

$\mathrm{B}$ ACKGROUND: N-acetyltransferase-2 (NAT2) enzyme, encoded by NAT2 gene, plays a key role in metabolism of anti-tuberculosis (TB) drug isoniazid. Polymorphisms in NAT2 gene may result in different responses to TB therapy. Since TB prevalence in the eastern part of Indonesia is high, the aim of this study is to explore the distribution of NAT2 gene polymorphisms among population from Kupang, Nusa Tenggara Timur.

METHODS: A total of 234 respondents were included from Kupang in 2012. Polymorphisms of NAT2 gene were examined using mass screening platform and the genotypes distribution were presented in percentage. To confirm NAT2 gene polymorphisms, polymerase chain reaction (PCR)-sequencing was performed in a subset of population.
RESULTS: The polymorphisms of NAT2 gene showed that the distribution of rs1801279 for GG genotype was $100 \%$; whereas the genotype distribution of rs 1799930 for GG, GA and AA was $57 \%, 35.1 \%$ and $7.9 \%$, respectively. In a subset of individuals (n13), acetylator status was well determined by PCR-sequencing, resulting in individual with wild type fast acetylator (NAT2*4; n4), intermediate (NAT $2 * 4 / 5$ or NAT $2 * 4 / * 6$ or NAT2 $* 4 / * 7 ;$ n 7 ) and poor acetylators $(\mathrm{NAT} 2 * 6 / * 6$ or NAT2 $* 7 / * 7 ; \mathrm{n} 2)$.

CONCLUSION: The amino acid change in rs1799930 result in intermediate and poor acetylator status in Kupang population. This may lead to suboptimal response of TB therapy. Assessing acetylator status before TB therapy is important and may serve as personalized INH therapy.

KEYWORDS: NAT2 gene, polymorphism, acetylator status, Kupang

Indones Biomed J. 2018; 10(1): 56-61

\section{Introduction}

$\mathrm{N}$-acetyltransferase-2 (NAT2) enzyme plays a key role in metabolism of a variety of drugs, including anti-tuberculosis (TB) drug isoniazid (INH).(1) This enzyme is encoded by polymorphic NAT2 gene which is located at chromosome 8 , identified as $8 \mathrm{p} 22$. There are at least 7 single nucleotide polymorphisms (SNPs) in NAT2 gene, i.e., nucleotide (nt) change of $191 \mathrm{G}>\mathrm{A}$ at $\mathrm{rs} 1801279, \mathrm{nt} 282 \mathrm{C}>\mathrm{T}$ at $\mathrm{rs} 1041983$, nt341 $\mathrm{T}>\mathrm{C}$ at rs 1801280, nt481C $>$ T at rs $1799929, \mathrm{nt} 590 \mathrm{G}>\mathrm{A}$ at $\mathrm{rs} 1799930$, nt803A $>\mathrm{G}$ at $\mathrm{rs} 1208$, and $\mathrm{nt} 857 \mathrm{G}>\mathrm{A}$ at rs1799931, respectively. The distribution of these SNPs is listed in the International data base and has been reported differently in various ethnicities around the globe.(2)

Of note, the nucleotide change does not always result in a change of coded amino acid, for example at the position $\mathrm{nt} 282 \mathrm{C}>\mathrm{T}$ and $\mathrm{nt} 481 \mathrm{C}>\mathrm{T}$; whereas in other positions amino acid do change, for example at the position nt590G $>$ A there is a change from arginine (Arg) to glutamine (Gln) 
or at the position nt857 there is a change from glycine (Gly) to glutamic acid (Glu). Combination of these SNPs determines haplotypes of NAT2 gene result in various host acetylator status, that influences the NAT2 enzyme activity. For example, two normal allele of NAT2*4 or homozygous wild-type, designated as NAT $2 * 4 / * 4$ genotypes has fast or rapid enzyme activity, and this individual is identified as rapid or fast acetylator; whereas poor or slow acetylator has two mutant alleles with possible combination of genotypes such as nt $481 \mathrm{C}>\mathrm{T}$, nt590G $>A$ or $n t 857 \mathrm{G}>\mathrm{A}$, designated as NAT2 $* 5, \mathrm{NAT} 2 * 6$ or NAT2 $* 7$, respectively. Intermediate acetylator has one normal allele NAT2*4 in combination with one mutant allele NAT2*5, NAT $2 * 6$ or NAT2*7.(3) Rapid acetylator may develop in a suboptimal dose of drugs. In the other side of the coin, slow acetylator individuals may develop in an overdose leading to drug-induced hepatotoxicity or adverse drugs response. Therefore, adjustment of INH dose in TB therapy might be needed and serve as a personalized medicine.(4) Likewise the distribution of NAT2 polymorphisms, the prevalence of acetylator status have been reported differently in various ethnicities. $(5,6,7)$

A study in Java island, located in the western part of Indonesia, has shown that slow acetylator is occurred in $35 \%$ of the population.(8) This might have an impact in the management of TB therapy, especially since Indonesia ranks second in TB prevalence in the world.(9) The high frequency of slow acetylators in this western part of Indonesia raises some concerns for TB therapy complication resulting in INH-induced hepatitis. INH has been used as preventive therapy according to National TB Program in high burden TB countries, and this may increase the role of screening of the acetylator status in the population. Therefore, acetylator status detection is needed since this acetylator status is clinically relevant prior to INH therapy to adjust the dose of treatment.

There are several methods to determine the host acetylator status (1) i.e., polymerase chain reaction (PCR)restriction fragment length polymorphism (RFLP), PCRdirect sequencing and many other recent new techniques using automatic genotyping SNP platform for robust mass screening.(10) The aim of this study was to explore the NAT2 gene polymorphisms and to determine the acetylator status by using mass screening platform among population in Kupang, a region in the eastern part of Indonesia where TB prevalence is higher compared to the west.(11) Moreover, the ethnicity in Kupang is originally different compared to ethnicity in Java. Therefore, acetylator status study in the eastern part of Indonesia might give valuable information for TB control program in Indonesia.

\section{Methods}

This study was part of a larger study identifying susceptibility genes related to TB infection in the city of Kupang, Nusa Tenggara Timur, Indonesia. The initial study recruited newly TB patients (n124) diagnosed from Prof. Dr. W. Z. Johannes Hospital in Kupang and their healthy controls (n124) from the same house where TB patients lived. In brief, TB patients were diagnosed according to the standard hospital procedure as directed in WHO guideline, including history taking of TB infection, physical examination, chest $\mathrm{X}$-ray, positive sputum, and positive mycobacterial culture. Patients with HIV and Diabetes Mellitus (n14) were excluded previously in the susceptibility study to TB.

This study explored NAT2 gene polymorhpisms in the population, thus both patients and control (n234) who were originally 'by saying' from ethnicity in the Timor island, where Kupang is located, were included in this current NAT2 gene study. The last name of the respondents would confirm the ethnicity from Timor island. No further exclusion criteria in this study since all participants with the same ethnicity would represent the genetic background of population. After reading and explaining the information of the study, all participants signed informed consent. The ethical clearance was approved by the Ethical Committee from Faculty of Medicine Universitas Padjadjaran Bandung under No.136/UN6.C2.1.2/KEPK/PN/2012.

Vein blood was drawn and collected in a $3 \mathrm{~mL}$ EDTA tube and stored in cold condition $(+4 \mathrm{C})$ prior sending to Bandung located in Java island, in the Western part of Indonesia, where DNA was isolated according to the manufacturer's protocol (QIAamp DNA Blood Mini Kit, Cat No.51104, Qiagen).

\section{Genotyping of Single Nucleotide Polymorphisms in NAT2 Gene}

In total, 7 polymorphisms in NAT2 gene, including $191 \mathrm{G}>\mathrm{A}$ at $\mathrm{rs} 1801279, \mathrm{nt} 282 \mathrm{C}>\mathrm{T}$ at $\mathrm{rs} 1041983, \mathrm{nt} 341 \mathrm{~T}>\mathrm{C}$ at $\mathrm{rs} 1801280, \mathrm{nt} 481 \mathrm{C}>\mathrm{T}$ at $\mathrm{rs} 1799929, \mathrm{nt590G}>\mathrm{A}$ at rs 1799930, nt803A $>\mathrm{G}$ at $\mathrm{rs} 1208$, and $\mathrm{nt} 857 \mathrm{G}>\mathrm{A}$ at rs1799931, were examined (the GoldenGate ${ }^{\circledR}$ Genotyping Assay for VeraCode $\AA /$ BeadXpress Illumina $\left.{ }^{\circledR}\right)$. The machine used in this study can mass screen of 96 participants in each plate and detect up to 48 SNPs. In brief, DNA was activated to bind to paramagnetic samples, and hybridization was followed according to manufacturer's protocol. Microbead code was then identified and fluorescent signal was detected (BeadXpress ${ }^{\circledR}$ Reader). During scanning, a laser beam penetrates the digitally inscribed to generate a unique code 
image. Data was generated and analyzed by data analysis software (Illumina's GenomeStudio ${ }^{\circledR}$ ). The distribution of each allele and genotype of each rs number were counted for the frequency and compared to published global frequency. $(16,19)$

\section{NAT2 Gene Sequencing}

To confirm the polymorphisms in NAT2 gene, NAT2 gene was sequenced. In brief, forward primer of 5'-GGG ATC ATG GAC ATT GAA GC-3' and reverse primer of 5'-GGG TGA TAC ATA CAC AAG GGT TTA-3' were self-designed. The total volume of $50 \mu \mathrm{L}$ PCR solution consisting of $25 \mu \mathrm{L}$ Master Mix solution (Kappa2G Fast, Kapabiosystems), $19 \mu \mathrm{L}$ deionized water, $2 \mu \mathrm{L}$ forward primer, $2 \mu \mathrm{L}$ reverse primer, and $2 \mu \mathrm{L}$ of the DNA. The PCR condition was initial denaturation at $94^{\circ} \mathrm{C}$ for $3 \mathrm{~min}$, followed by 30 cycles of denaturation at $94^{\circ} \mathrm{C}$ for $30 \mathrm{sec}$, annealing at $55^{\circ} \mathrm{C}$ for 30 sec, and extension at $72^{\circ} \mathrm{C}$ for $1 \mathrm{~min}$ with the final extension at $72^{\circ} \mathrm{C}$ for $5 \mathrm{~min}$. PCR product of $870 \mathrm{bp}$ was visualized on $1 \%$ agarose gel running for $20 \mathrm{~min}$ at $90 \mathrm{~V}$ before further sequencing process (BigDye ${ }^{\circledR}$ Terminator v3.1 cycle sequencing, done by the 1st BASE, Kuala Lumpur).

\section{Acetylator Status Determination from 7 Polymorphisms in NAT2 Gene}

The acetylator status determination was assessed using 7 most important NAT2 SNP i.e., rs 1801279 for $191 \mathrm{G}>\mathrm{A}$, rs 1041983 for $282 \mathrm{C}>\mathrm{T}$, rs 1801280 for $341 \mathrm{~T}>\mathrm{C}$, rs 1799929 for $481 \mathrm{C}>\mathrm{T}$, rs 1799930 for $590 \mathrm{G}>\mathrm{A}$, rs 1208 for $803 \mathrm{~A}>\mathrm{G}$, and rs1799931 for $857 \mathrm{G}>\mathrm{A}$. Individual is classified as fast, intermediate, or slow acetylator, depending on NAT2 diplotypes, as published elsewhere.(12) The nucleotide change at rs1801280 $341 \mathrm{~T}>\mathrm{C}$, rs1799930 $590 \mathrm{G}>\mathrm{A}$, and rs $1799931857 \mathrm{G}>\mathrm{A}$, were designated as NAT2*5, NAT2*6, NAT2*7, respectively.

\section{Results}

In total, 234 participants with ethnicity from Timor island area were included in this study, consisting of 107 male (45.7\%) and 127 female (54.3\%) with mean age of 36.7 years old (SD 13.6 years old). In a mass screening of 7 polymorphisms in NAT2 gene, only 2 of 7 positions were detected i.e., rs1801279 or nt191 for nucleotide change of $\mathrm{G}>\mathrm{A}$ and rs1799930 or nt590 for nucleotide change of $\mathrm{G}>\mathrm{A}$. The genotype frequency of rs1801279 showed $100 \% \mathrm{GG}$, thus it was monomorphic; whereas rs 1799930 showed genotype frequency of GG, GA and AA for $57 \%$, $35,1 \%, 7.9 \%$, respectively, as summarized in Table 1 .
Table 1. Distribution of SNPs NAT2 gene at rs1801279 and rs1799930 in population from Kupang.

\begin{tabular}{llccc}
\hline \multicolumn{1}{c}{ rs number } & Nucleotide & GG (\%) & GA (\%) & AA (\%) \\
\hline rs1801279 & nt191 G $>$ A & 100 & 0 & 0 \\
rs1799930 & nt590 G $>$ A & 57 & 35.1 & 7.9 \\
\hline
\end{tabular}

Frequencies of the genotypes in one plate of 96 individual were also depicted for rs1801279 (Figure1) and for rs1799930 (Figure 2) as shown using GenomeStudio ${ }^{\circledR}$. Furthermore, rs1801279 and rs1799930 genotype distribution in Kupang was compared to other population, showing similarity to population studied in East Asian countries (Figure 3) (16,19).

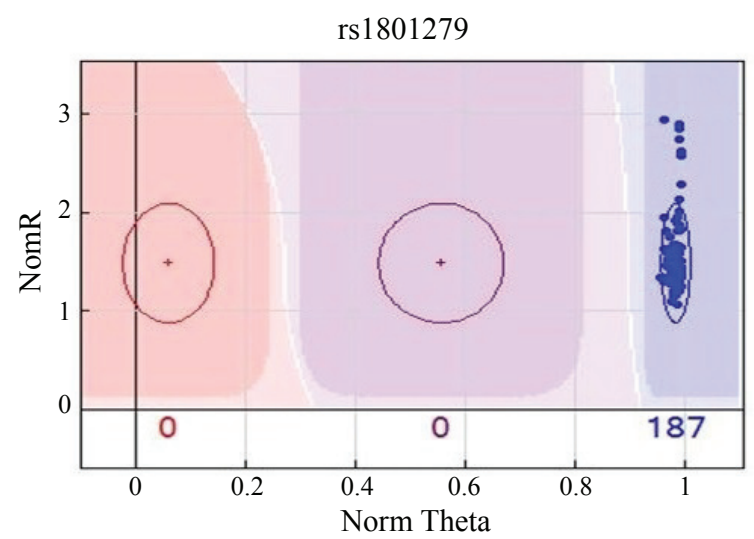

Figure 1. Distribution of SNP NAT2 gene rs 1801279 in population from Kupang, as shown using Illumina's GenomeStudio®. Every single dot represents individuals genotyped in one plate for 96 individuals. Pink area is designated as genotype AA, purple area as GA, blue area as GG (wild type), respectively.

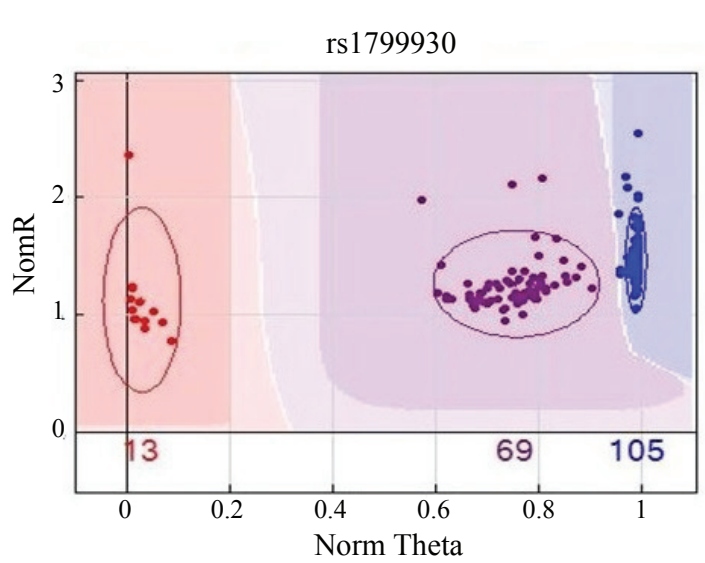

Figure 2. Distribution of SNP NAT2 gene rs 1799930 in population from Kupang, as shown using Illumina's GenomeStudio®. Every single dot represents individuals genotyped in one plate for 96 individuals. Pink area is designated as genotype AA, purple area as GA, blue area as GG (wild type), respectively. 
rs 1801279

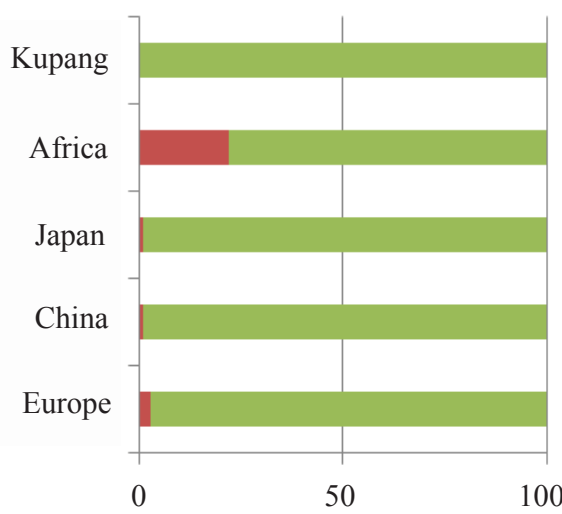

rs1799930

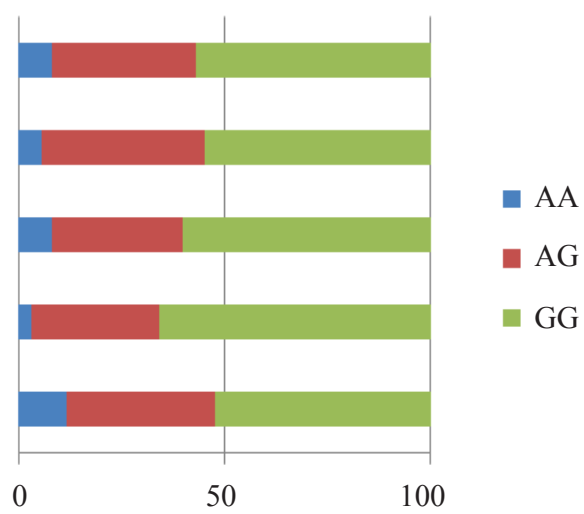

Figure 3. The distribution of rs180279 and rs1799930 in population from Kupang compared to other populations.

In a subset of the population (n13), acetylator status was well determined using PCR-sequencing method, resulting in individuals with rapid acetylators (NAT2*4/*4; $\mathrm{n}=4$ ), intermediate acetylators ( 7 , including NAT $2 * 4 / * 5$ $\mathrm{n}=1 ; \mathrm{NAT} 2 * 4 / * \mathrm{n}=1 ; \mathrm{NAT} 2 * 4 * 7 \mathrm{n}=5)$ and poor acetylators (n2, including NAT2*6/*6n=1;NAT2*7/*7n=1) as detailed in Table 2. Furthermore, we have assessed the results of rs1801279 and rs1799930 using PCR-sequencing and using mass-screening, and verified that both results were similar.

\section{Discussion}

TB is an infectious disease, caused by mycobacterium tuberculosis. INH has been used as one of the antiTB therapy according to WHO guideline (9) and also encouraged for preventive drug in children.(13) NAT2 enzyme plays a key role in metabolism of INH. To control the TB prevalence in high burden area, host genetic factor, among others NAT2 gene polymorphisms may play an

Table 2. The polymorphisms in NAT2 gene and acetylator status determination in a subset of population from Kupang, East Nusa Tenggara, using PCR-sequencing method.

\begin{tabular}{|c|c|c|c|c|c|c|c|c|}
\hline & rs 1801279 & rs 1041983 & rs 1801280 & rs1799929 & rs1799930 & rs 1208 & rs 1799931 & \multirow{4}{*}{$\begin{array}{l}\text { Acetylator } \\
\text { phenotype }\end{array}$} \\
\hline $\begin{array}{l}\text { Nucleotide } \\
\text { change }\end{array}$ & $191 \mathrm{G}>\mathrm{A}$ & $282 \mathrm{C}>\mathrm{T}$ & $341 \mathrm{~T}>\mathrm{C}$ & $481 \mathrm{C}>\mathrm{T}$ & $590 \mathrm{G}>A$ & $803 \mathrm{~A}>\mathrm{G}$ & $857 \mathrm{G}>\mathrm{A}$ & \\
\hline $\begin{array}{l}\text { Amino acid } \\
\text { change }\end{array}$ & R64Q & $\begin{array}{c}\text { Y94Y } \\
\text { (synonymous) }\end{array}$ & I114T & $\begin{array}{c}\text { L161L } \\
\text { (synonymous) }\end{array}$ & R197Q & K268R & G286E & \\
\hline $\begin{array}{l}\text { NAT2 } \\
\text { haplotype }\end{array}$ & & & NAT2 $* 5$ & & NAT2 $* 6$ & & NAT2 $* 7$ & \\
\hline NAT2 $* 4$ & . & . & . & . & . & . & . & Fast/Rapid \\
\hline $\mathrm{NAT} 2 * 4$ & . & . & . & . & . & . & . & Fast/Rapid \\
\hline NAT2 $* 4$ & . & . & . & . & . & . & . & Fast/Rapid \\
\hline NAT2*4 & . & . & . & . & . & . & . & Fast/Rapid \\
\hline NAT2 $* 4 / * 5$ & . & $\mathrm{CT}$ & $\mathrm{TC}$ & $\mathrm{CT}$ & . & . & . & Intermediate \\
\hline NAT $2 * 4 / * 6$ & . & $\mathrm{CT}$ & . & . & GA & . & . & Intermediate \\
\hline NAT2 $* 4 / * 7$ & . & $\mathrm{CT}$ & . & . & . & . & GA & Intermediate \\
\hline NAT2 $* 4 / * 7$ & . & $\mathrm{CT}$ & . & . & . & . & GA & Intermediate \\
\hline NAT2 $* 4 / * 7$ & . & $\mathrm{TT}$ & . & . & GA & . & GA & Intermediate \\
\hline $\mathrm{NAT} 2 * 4 / * 7$ & . & $\mathrm{TT}$ & . & . & GA & . & GA & Intermediate \\
\hline NAT2 $* 4 / * 7$ & . & $\mathrm{TT}$ & . & . & GA & . & GA & Intermediate \\
\hline NAT $2 * 6 / * 6$ & . & $\mathrm{TT}$ & . & . & AA & . & . & Poor \\
\hline NAT2*7/*7 & . & $\mathrm{TT}$ & . & . & . & . & $\mathrm{AA}$ & Poor \\
\hline
\end{tabular}


important role in response to TB therapy. Our study describes the distribution of NAT2 gene polymorphisms in population in Kupang, Nusa Tenggara Timur, Indonesia, where TB prevalence in this area is high. Ideally, to have NAT2 prevalence in an particular area or community, randomized community samples should be used. However, since NAT2 gene is close related to pharmacogenomics in TB, we have used the respondents consisting of TB patients and their controls to represent the prevalence in Kupang, that limits our current study. Nevertheless, assessing the NAT2 gene polymorphisms and thus the acetylator status in an area where TB prevalence is high, may optimize the strategy of TB control.

The NAT2 gene polymorphisms distribution has been reported differently in various ethnicities worldwide and this NAT2 gene diversity may have implications for NAT2 evolutionary history.(14) Our result has shown that the monomorphic rs1801279 genotype distribution in Kupang was similar to population studied in the neighbor land Thailand (15) and many other East Asian population.(16) Interestingly, the study from Africa showed a very different distribution compared to the Kupang population.(16) In the case of population from Kupang and Timor island, this may be not true since the genetic background of this population is presumed to be derived from the African origin. African genetic diversity in human and pathogen may have implications for human demographic history, modern human origins, and complex disease mapping.(17) Previous group in Kupang has showed that mycobacterium tuberculosis Family F (East African-Indian) and family D (Latin American and Mediterranean) were more prevalent to infect the population in Timor $(33.3 \%$ and $20.0 \%$, respectively), suggesting a host-pathogen relation.(18) As for rs 1799930, genotype distribution from Kupang does not differ that much compared to global population.(19)

Ebeshi, et al., has shown that the most common SNPs in NAT2 gene that play a key role are the nucleotide change at rs1801279 or $191 \mathrm{G}>\mathrm{A}, \operatorname{rs} 1801280341 \mathrm{~T}>\mathrm{C}$, rs1799930 $590 \mathrm{G}>\mathrm{A}$, and rs1799931 $857 \mathrm{G}>\mathrm{A}$, as those mutations alone or in combination might have changes in activity, stability or specificity of NAT2 enzyme.(7) Since only 2 polymorphisms data were available in our study, the complete acetylator status of these population could not be determined. The monomorphic rs1801279 genotype in this study does not account for the acetylator status determination. The rs 1799930 polymorphisms in our study showed that there is a nucleotide change from guanine to adenine. This amino acid change from Arg to Gln at R197Q, designated as NAT2*6, indicating that the slow acetylators (AA genotype) and intermediate acetylators (GA genotype) in this population is accounted for at least $7.9 \%$ and $35.1 \%$, respectively. If data of other SNP i.e., rs1801280 $341 \mathrm{~T}>\mathrm{C}(\mathrm{NAT2} * 5)$ and $\mathrm{rs} 1799931857 \mathrm{G}>\mathrm{A}$ (NAT2*7) available, the percentage of slow acetylator could be counted and compared with the study in Jakarta, which is around $40 \%$.(8) The slow acetylator may develop drug induced liver intoxicity, therefore, this high percentage is alarming, since Indonesia has high TB prevalence, being the second worldwide.(9)

Furthermore, geographic and ethnic variation in the frequency of NAT2 genotypes associated with rapid or intermediate acetylator $(5,6)$, as well as slow acetylator (20) have been reported. Pharmacology study in Japan clearly showed, that the metabolism of INH by NAT2 enzyme is impaired in subjects with NAT2 gene mutations (21), however, study in Chinese population could not find any significant association between NAT2 gene genotype and the hepatotoxicity.(22) Although it is still questionable, whether NAT2 genotype is necessary for personalize INH doses (23), study in Indonesia confirms a significant association between slow acetylators and susceptibility to liver injury induced by INH.(24) Further pharmacogenetic study in Indonesia is needed to explore the association between NAT2 gene polymorphisms and INH metabolism.

The limitation of this study is that the mass screening of NAT2 gene polymorphism cannot be optimally conducted, however, individual screening by using PCRsequencing method can still be well performed to determine acetylator status. Since the acetylator status is clinically relevant prior to INH therapy to adjust the dose of treatment, especially in the area where TB prevalence is high, we therefore suggest that individual NAT2 PCR-sequencing method is suitable to guide for a personalized therapy for successful TB treatment.

\section{Conclusion}

The rs1801279 NAT2 gene in population from Kupang is monomorphic, whereas based on the distribution of rs1799930 or nt590 polymorphism, it is predicted that the intermediate (GA genotype) and poor acetylator (AA genotype) in population from Kupang is as low as $35.1 \%$ and $7.9 \%$, respectively. It is worthy noted that acetylator status determination is needed, especially in the high TB burden area. PCR-sequencing of NAT2 gene is of great help in determining acetylator status. 


\section{Acknowledgment}

The study was financially supported by the University Grant Year 2012. We are greatly thankful to Kinasih Prayuni and Fajar Muhammad for their technical support, to Novi Vicahyani Utami, Ratu Safitri and Tri Hanggono Achmad for fruitful and constructive discussions.

\section{References}

1. Sotsuka T, Sasaki Y, Hirai S, Yamagishi F, Ueno K. Association of isoniazid-metabolizing enzyme genotypes and isoniazid-induced hepatotoxicity in tuberculosis patients. In Vivo. 2011; 25: 803-12.

2. Hein DW, Doll MA. Accuracy of various human NAT2 SNP genotyping panels to infer rapid, intermediate and slow acetylator phenotypes. Pharmacogenomics J. 2012; 13: 31-41.

3. Fukino K, Sasaki Y, Hirai S, Nakamura T, Hashimoto M, Yamagishi $\mathrm{F}$, et al. Effects of $\mathrm{N}$-acetyltransferase 2 (NAT2), CYP2E1 and Glutathione-S-transferase (GST) genotypes on the serum concentrations of isoniazid and metabolites in tuberculosis patients. J Toxicol Sci. 2008; 33: 187-95.

4. Azuma J, Ohno M, Kubota R, Yokota S, Nagai T, Tsuyuguchi K, et al. NAT2 genotype guided regimen reduces isoniazid-induced liver injury and early treatment failure in the 6-month four-drug standard treatment of tubercu-losis: a randomized controlled trial for pharmacogenetics-based therapy. Eur J Clin Pharmacol. 2013; 69: 1091-101.

5. Kang TS, Jin SK, Lee JE, Woo SW, Roh J. Comparison of genetic polymorphisms of the NAT2 gene between Korean and four other ethnic groups. J Clin Pharm Ther. 2009; 34: 709-18.

6. Chamorro JG, Castagnino JP, Musella RM, Frias A, Aranda FM, De Larrañaga GF. The distribution of allelic and genotypic frequencies of N-Acetyltransferase-2 variants in an Argentine population. J Infect Dev Ctries. 2012; 6: 671-4.

7. Ebeshi BU, Bolaji OO, Masimirembwa CM. Arylamine N-acetyltransferase 2 (NAT2) single nucleotide polymorphisms frequencies in Nigerian populations. Afr J Pharm and Pharmacol Res. 2011; 1: 001-6.

8. Yuliwulandari R, Sachrowardi Q, Nishida N, Takasu M, Batubara L, Susmiarsih TP, et al. Polymorphisms of promoter and coding regions of the arylamine $\mathrm{N}$-acetyltransferase 2 (NAT2) gene in the Indonesian population: proposal for a new nomenclature. J Hum Genet. 2008; 53: 201-9.

9. World Health Organization (WHO). Global Tuberculosis Report. Geneva: WHO; 2015.
10. Lin CH, Yeakley JM, McDaniel TK, Shen R. Medium- to highthroughput SNP genotyping using VeraCode microbeads. Methods Mol Biol. 2009; 496: 129-42.

11. Ministry of Health Republic of Indonesia. Basic Health Research. Jakarta: Ministry of Health Republic of Indonesia; 2013.

12. Mayo Clinic: Mayo Medical Laboratories [Internet]. NAT2 N-Acetyltrasferase 2 Gene (NAT2), Full Gene Sequence [cited 2017 Mar 25]. Available from: http://www.mayomedicallaboratories. com/test-catalog/Clinical+and+Interpretive/83389.

13. Rutherford ME, Ruslami R, Maharani W, Yulita I, Lovell S, Van Crevel $\mathrm{R}$, et al. Adherence to isoniazid preventive therapy in Indonesian children: A quantitative and qualitative investigation. BMC Res Notes. 2012; 5: 7. doi: 10.1186/1756-0500-5-7.

14. Sabbagh A, Langaney A, Darlu P, Gérard N, Krishnamoorthy R, Poloni ES. Worldwide distribution of NAT2 diversity: implications for NAT2 evolutionary history. BMC Genet. 2008; 9: 21. doi: 10.1186/1471-2156-9-21.

15. Kukongviriyapan V, Prawan A, Tassaneyakul W, Aiemsa-Ard J, Warasiha B. Arylamine $\mathrm{N}$-acetyltransferase-2 genotypes in the Thai population. Br J Clin Pharmacol. 2003; 55: 278-81.

16. SNPedia [Internet]. Rs1801279 [updated 2012 Dec 5; cited 2013 Sep 1]. Available from: http://snpedia.com/index.php/Rs1801279.

17. Campbell MC, Tishkoff SA. African genetic diversity: implications for human demographic history, modern human origins, and complex disease mapping. Annu Rev Genomics Hum Genet. 2008; 9: 403-33.

18. Parwati I, van Crevel R, Sudiro M, Alisjahbana B, Pakasi T, Kremer $\mathrm{K}$, van der Zanden A, van Soolingen D. Mycobacterium tuberculosis population structures differ significantly on two Indonesian Islands. J Clin Microbiol. 2008; 46: 3639-45.

19. SNPedia [Internet]. Rs1799930 [updated 2012 Dec 5; cited 2013 Sep 1]. Available from: http://snpedia.com/index.php/Rs1799930.

20. Lin HJ, Han CY, Lin BK, Hardy S. Ethnic distribution of slow acetylator mutations in the polymorphic $\mathrm{N}$-acetyltransferase (NAT2) gene. Pharmacogenetics J. 1994; 4: 125-34.

21. Kita T, Tanigawara Y, Chikazawa S, Hatanaka H, Sakaeda T, Komada $\mathrm{F}$, et al. N-Acetyltransferase2 genotype correlated with isoniazid acetylation in Japanese tuberculous patients. Biol Pharm Bull. 2001; 24: 544-9.

22. Lv X, Tang S, Xia Y, Zhang Y, Wu S, Yang Z, et al. NAT2 genetic polymorphisms and anti-tuberculosis drug-induced hepatotoxicity in Chinese community population. Ann Hepatol. 2012; 11: 700-7.

23. Kinzig-Schippers M, Tomalik-Scharte D, Jetter A, Scheidel B, Jakob $\mathrm{V}$, Rodamer M, et al. Should we use N-acetyltransferase type 2 genotyping to personalize isoniaziddoses? Antimicrob Agents Chemother. 2005; 49: 1733-8.

24. Yuliwulandari R, Susilowati RW, Wicaksono BD, Viyati K, Prayuni $\mathrm{K}$, Razari I, et al. NAT2 variants are associated with drug-induced liver injury caused by anti-tuberculosis drugs in Indonesian patients with tuberculosis. J Hum Genet. 2016; 61: 533-7. 